\title{
Intra-test heterogeneity in trace element composition of Amphistegina lessonii as proxy of ambient seawater temperature and tidal height
}

\author{
SONAL KHANOLKAR ${ }^{1}$, RALF SCHIEBEL ${ }^{1}$, ASMITA \\ SINGH $^{2}$, PRATUL KUMAR SARASWATI ${ }^{2}$, KLAUS PETER \\ JOCHUM ${ }^{1}$, ULRIKE WEIS ${ }^{1}$, BRIGITTE STOLL ${ }^{1}$ AND \\ GERALD H. HAUG ${ }^{1,3}$
}

${ }^{1}$ Max Planck Institute for Chemistry

${ }^{2}$ Indian Institute of Technology Bombay

${ }^{3}$ ETH Zurich

Presenting Author: sonal.khanolkar@mpic.de

Amphistegina is a larger benthic foraminifer (LBF) commonly found within the modern coral reefs, and a major contributor to the $\mathrm{CaCO}_{3}$ budget of shallow marine environments. As the family Amphisteginidae occurs through the Cenozoic, the potential as an archive for paleoclimate reconstruction is explored. We analyzed adult microspheric specimens of Amphistegina lessonii collected in September 2003, November 2003, January 2004, and March 2004, from 2 meters water depth in the coral reefs of Akajima, Okinawa, Japan. The intra-test variability in trace elements of $A$. lessonii was investigated using femtosecond-laser ablation-inductively coupled plasma-mass spectrometry (fs-LA-ICP-MS) of the nine specimens from the outermost to innermost chamber. Tests of $A$. lessonii were analyzed for $\mathrm{Mg} / \mathrm{Ca}, \mathrm{Na} / \mathrm{Ca}$, and $\mathrm{Sr} / \mathrm{Ca}$ along the septa to observe Test Size-Lifespan relationships. The lifespan of a specimen of $A$. lessonii of $1200 \mu \mathrm{m}$ in diameter is estimated at $\sim 3$ months and $\sim 2$ months for specimens $900 \mu \mathrm{m}$ in size. Over the estimated lifespans, $\mathrm{Mg} / \mathrm{Ca}$ of individual specimens of $A$. lessonii is highly variable and displays co-variation with temperature and tidal height. High tides may increase sediment re-suspension and light attenuation thus leading to high $\mathrm{Mg} / \mathrm{Ca}$ values within the calcareous shell of $A$. lessonii, analogous to similar mechanisms described for the symbiont-bearing planktic foraminifers. $\mathrm{Na} / \mathrm{Ca}$ and $\mathrm{Sr} / \mathrm{Ca}$ show no correlation or covariation with tidal height or temperature. A significant correlation between $\mathrm{Mg} / \mathrm{Ca}$ and sea surface temperature can be described by the equation $\mathrm{Mg} / \mathrm{Ca}(\mathrm{mmol} / \mathrm{mol})=25.904 \mathrm{e}^{0.0172} \mathrm{~T} \pm 1.31\left(\mathrm{R}^{2}=\right.$ $0.78, \mathrm{p}<0.05$ ) (Khanolkar et al., 2021). Future projects may apply and further develop this approach for the reconstruction of the tropical shallow marine paleoenvironments.

Khanolkar, S., Schiebel, R., Singh, A., Saraswati, P. K., Jochum, K. P., Weis, U., Stoll, B., Haug, G. H. (2021). Intra-test variations in trace element composition of Amphistegina lessonii using femtosecond-laser ablation-ICP-mass spectrometry: A field study from Akajima, Okinawa Prefecture, Japan. Geochemistry, Geophysics, Geosystems, 22, e2020GC009443. https://doi.org/10.1029/2020GC009443 